\section{Internet and decision-making regarding health among pregnant woman: cross-cultural adaptation of a questionnaire for use in Brazil}

\author{
A Internet e tomada de decisões sobre saúde \\ entre gestantes: uma adaptação transcultural \\ de um questionário para uso no Brasil
}

Internet y toma de decisiones respecto a la salud entre mujeres embarazadas: adaptación transcultural de un cuestionario para su uso en Brasil
Ana Carolina Cleto Borges 1 Raquel Conceição Ferreira 1 Lorrany Gabriela Rodrigues 1 Matheus França Perazzo 1 Saul Martins Paiva 1 Maria Inês Barreiros Senna 1

doi: 10.1590/0102-311X00244019

\begin{abstract}
The aim of this study was to translate and cross-culturally adapt the Women's Use of the Internet in Pregnancy Questionnaire (WUIPQ) to Brazilian Portuguese and analyze the psychometric properties of the Preparation for Decision Making Scale (PDMS). This study consisted of the following steps: translation, synthesis, back-translation, evaluation by the author of the original questionnaire, review by the panel of experts, and pretest of the WUIPQ. For such, Brazilian pregnant women and mothers who were members of Facebook groups participated in the study. We measured test-retest reliability as well as internal consistency and performed confirmatory factor analysis (CFA) of the B-PDMS. In the pretest, $88.14 \%$ of the participants considered the items of the B-WUIPQ to be clear and pertinent, and $84.09 \%$ rated the sequence and organization of the questionnaire as excellent/good. The intraclass correlation coefficient and Cronbach's alpha coefficient for the B-PDMS were 0.850 (95\%CI: 0.791-0.899) and 0.91, respectively. CFA revealed factor loadings higher than 0.70 for most items, with a comparative fit index of 0.989, Tucker-Lewis index of 0.984, and root mean square error of approximation of 0.08 (95\%CI: 0.06-0.09). The B-WUIPQ presented crosscultural adapted, and the B-PDMS demonstrated satisfactory psychometric proprieties to Brazilian pregnant women.
\end{abstract}

Pregnant Women; Internet; Access to Information; Cross-cultural Comparison; Surveys and Questionnaire

\author{
Correspondence \\ L. G. Rodrigues \\ Faculdade de Odontologia, Universidade Federal de Minas \\ Gerais. \\ Rua Prof. Moacir Gomes de Freitas 688, Belo Horizonte, MG \\ 31270-901, Brasil. \\ lorranygrodrigues@gmail.com \\ 1 Faculdade de Odontologia, Universidade Federal de Minas \\ Gerais, Belo Horizonte, Brasil.
}




\section{Introduction}

The Internet is considered the main source of information on health among pregnant women 1,2,3. It is a fast, easy, and accessible resource 2,3,4,5,6,7 and the Google search website is the most widely used by this population 1,8,9. The most researched topics correspond to the phases of fetal development and nutrition during pregnancy $5,8,9,10,11$. Social media are also cited as a source of information and an important tool to provide emotional support and to sharing of experiences, assisting in the decrease of stress levels and improvements in general health 12 . One of the reasons for the use of the Internet is the search for information to support more conscious health-related decision-making in the gestational period $1,4,5,6,11,12,13,14$.

The limited educational practices at public healthcare services in Brazil 15 may contribute to the online search for information due to the need for pregnant women to complement the counseling received during prenatal follow-up 1,11,14. Thus, studies on the use and influence of the Internet on health-related decision-making among Brazilian pregnant women may help identify the potential of the Internet for empowering these women in regarding decision-making. Such studies can highlight the effects of online information in the relationship between patient and healthcare provider during prenatal appointments. Additionally, the results may alert healthcare providers to the need of having discussions with their patients on information obtained from the Internet, as well as to counsel them on reliable websites and optimize prenatal care and educational practices by extending care to the virtual environment, thus offering reliable information to this public 1,5,8,10,11,16,17,18,19.

Due to the lack of validated tools on this topic in Brazil, a search of the international literature was performed to find a questionnaire that could be cross-culturally adapted. This process is considered to be less time-consuming than the development of a new assessment tool 20 and favors comparison of results among different countries through a standardized, validated questionnaire 21 .

The Women's Use of the Internet in Pregnancy Questionnaire (WUIPQ) is based on the Information Search Process Model proposed by Kuhlthau 22. It was adapted to the Internet by Kalbach 23, while Lagan 24 included a scale to measure decision-making in this questionnaire, later adapted to pregnancy. A systematic review 25 included two highly regarded studies 1,11 that used this questionnaire. It has 71 items addressing how and why pregnant women use the Internet as a source of health information and its effect on decision-making during pregnancy ${ }^{1}$. Specialists have previously confirmed the content validity of this electronic questionnaire 24. The Preparation for Decision Making Scale (PDMS) 26 contains 11 items that make up the WUIPQ. The PDMS is based on a reflective model that assumes that these items manifest one underlying correlated construct. This construct is the utility and influence of the Internet in preparing pregnant women to communicate with health professionals and make health-related decisions during pregnancy 1 . This scale showed good reproducibility $(0.97)$ and satisfactory internal consistency (0.91) 1,24. Our study aimed to describe the translation and crosscultural adaptation of the WUIPQ and to present the psychometric properties of the Brazilian version of the PDMS (B-PDMS). The hypothesis raised by this study is that the Brazilian version of WUIPQ (B-WUIPQ) is equivalent to its original version and that the PDMS presents satisfactory psychometric properties for Brazilian pregnant women.

\section{Methods}

\section{Questionnaire}

The WUIPQ ${ }^{1}$ is composed of 71 items organized into sections that address the stages of the information search process: (i) reasons for seeking information on the Internet (15 items); (ii) choice of the Internet as a source of information (5 items); (iii) specific information accessed on the Internet (10 items); (iv) collection of online information (5 items); (v) evaluation of information (6 items); (vi) use of information and the influence of the Internet on decision-making related to pregnancy (16 items), (vii) sociodemographic aspects and skills of the respondent regarding the use of the Internet (14 items).

The PDMS has 11 items that compose section VI of the WUIPQ, and this scale was adapted by Lagan 24 to be used on pregnant women. Each item has five scored response options (not at all $=1$, 
very little $=2$, sometimes $=3$, often $=4$ and very often $=5$ ) 24 . Higher scores indicate greater use of the Internet for health-related decision making when communicating with healthcare providers during prenatal appointments 1 . The PDMS is a scale that manifests a theoretical construct, and its reliability and internal consistency were previously demonstrated 1,24. The PDMS may be used separately from WUIPQ.

\section{Study design}

The universalist approach was adopted to perform the translation and cross-cultural adaptation of the WUIPQ to Brazilian Portuguese 26,27,28,29,30, including the analysis of the equivalence of the concepts and items and establishment of the semantic equivalence. The measurement equivalence was performed to the Brazilian version of the PDMS.

\section{Equivalence of the concepts and items and semantic equivalence}

A panel of experts evaluated the equivalence of the concepts and items considering the original theoretical references as well as a literature review on the use of the Internet by pregnant women to seek health information. The panel of experts included four researchers in public health who were fluent in English and had experience with the cross-cultural adaptation and validation of research instruments.

The establishment of the semantic equivalence of the WUIPQ consisted of the following steps: translation, synthesis, back-translation, evaluation of the back-translated version by the author of the original questionnaire, revision by the panel of experts, and pre-test with the target population.

The translation of the WUIPQ was performed independently by two Brazilian translators fluent in English, resulting in two versions (T1 and T2). The first translator was a health professional, aware of the concepts and objectives of the questionnaire. The second was a professional translator who was unaware of the study purposes.

Experts created a synthesis version (T1.2) based on the $\mathrm{T} 1$ and $\mathrm{T} 2$ versions. This process involved selecting one of the translated versions and adapting the terms and expressions to Brazilian culture (healthcare practices of pregnant women in the prenatal period and childbirth in Brazil).

The T1.2 version was then back-translated into the original language by a native English-speaking translator fluent in Brazilian Portuguese who had no access to the original WUIPQ in English. The back-translated version (B1) was sent to the author of the original questionnaire for evaluation. The use of more acceptable terms for the Brazilian population was discussed with the author. The experts revised all versions (T1, T2, T1.2, B1) considering the author's comments regarding B1. The second synthesis of the WUIPQ resulted from expert consensus. This version was submitted to the pre-test.

The target population to pre-test were Brazilian pregnant women or mothers who gave birth less than one year earlier, aged 18 or older, who were residents of Brazil, and members of virtual groups for pregnant women and mothers on Facebook. For this step of this study, a convenience sample from a Facebook group of pregnant women and mothers was invited to participate through a letter with information regarding the study. The participants were required to evaluate each of the items on the questionnaire with regards to clarity, use of language and pertinence (adequate, partially adequate, or inadequate) as well as the sequence and organization of the questionnaire as a whole (excellent, good, fair, poor or very poor). A text box was also made available so that the respondent could propose different wording for each item. The pre-test was concluded with the saturation of the responses to all items. The translated WUIPQ, the statement of informed consent and the evaluation procedure were shared through the SurveyMonkey platform (https://www.surveymonkey.com). The expert panel analyzed the data quantitatively and qualitatively and the researchers discussed the suggestions from the target population until consensus was reached. The final adjustments gave rise to the pre-final Brazilian version of the questionnaire (B-WUIPQ), including the Brazilian version of the PDMS (B-PDMS).

\section{The measurement equivalence}

The aim of investigating measurement equivalence is to ensure that different language versions of the same instrument achieve acceptable levels of their psychometric properties. In this study, the internal 
consistency and dimensionality of the PDMS (B-PDMS) were evaluated in a sample of the target population. These psychometric properties were assessed by B-PDMS since only this part of WUIPQ is based on a reflexive model, in which the items reflect the construct in regard to health-related decisions during pregnancy 21. The original authors assessed the internal consistency of the PDMS, but they did not determine the scale dimensionality. Additionally, as performed by original authors, we tested the test-retest reliability for all questions of the B-WUIPQ.

To evaluate test-retest reliability, the B-WUIPQ, including B-PMDS, was administered to pregnant women and mothers who were members of four virtual groups on Facebook. A letter with the research instructions was posted recruiting women based on the eligibility criteria, inviting them to answer the questionnaire twice. A personalized link to access the questionnaire and statement of informed consent were sent via e-mail or Messenger to the women who expressed availability to participate twice, with intervals of 7 to 15 days. The agreement coefficients of the B-WUIPQ questions and the B-PDMS scale between two applications were evaluated using the intraclass correlation coefficient (ICC) (quantitative variable), simple (categorical variables), or weighted kappa (ordinal variables) according to variable characteristics. The two-way random effect model was used to calculate the ICC. For simple kappa in the presence of bias and prevalence index, the prevalence-adjusted bias-adjusted kappa (PABAK) was calculated 31. The linear weights were adopted to calculate the weight kappa. For categorical and ordinal variables, the percent agreement was also shown.

The internal consistency and the dimensionality of the B-PDMS were assessed in a sample of the target population. COSMIN (COnsensus-based Standards for the selection of health Measurement Instruments) guidelines were adopted to determine the size of the sample with at least four participants to each item of the questionnaire 21. In order to reach this sample, after approval obtained from group administrators, a link to the B-PDMS and a video with research instructions were posted in 118 groups between December 2017 and April 2018, excluding the four groups who were participants of the test-retest reliability. The sample did not include all group members, but rather those women who agreed to participate voluntarily.

Internal consistency of the B-PMDS was evaluated using Cronbach's alpha coefficient and the confirmatory factor analysis (CFA) to estimate this scale dimensionality. The CFA was performed using the weighted least square mean and variance (WLSMV) to indicate whether the variables observed were indicators for the latent variable (B-PDMS). A good latent variable exhibits convergent validity, demonstrating that its indicators measure the same construct, measured by factor loadings, which should be $>0.40$. The standard error and confidence interval were calculated using the bootstrap method with 1,000 replicates. The goodness-of-fit indicators were the Tucker-Lewis index (TLI), comparative fit index (CFI), and root mean square error of approximation (RMSEA). Values higher than 0.90 for the TLI and CFI and lower than 0.08 for RMSEA are considered adequate for a good fit 32,33. Stata version 15.0 (https://www.stata.com/) and Mplus version 8.3 (https://www.statmodel. $\mathrm{com} /$ ) were used for the statistical analysis.

\section{Ethical aspects}

This study received approval from the Human Research Ethics Committee of the Federal University of Minas Gerais, Brazil (process number: 65970517.6.0000.5149) and the participating women signed the Free and Informed Consent Form.

\section{Results}

\section{Equivalence of the concepts and items and semantic equivalence}

The panel of experts considered the concepts of the WUIPQ to be pertinent to its adaptation to Brazilian culture. The items were considered equivalent and applicable to the target population. Versions $\mathrm{T} 1$ and $\mathrm{T} 2$ differed on most items, but no semantic differences were found concerning the original questionnaire. The synthesis version (T1.2) was drafted based on the adaptations presented in Box 1. 
The back-translated version (B1) had no errors or inconsistencies when compared to the original version. The author of the questionnaire recommended a revision of the definition of "prognosis" (forecast) in item 12, which was presented in the T1.2 version as "prognóstico" (consequence). The revision performed by the panel of experts indicated new adjustments for items 7, 12, 31, 32, 59 and 64 (Box 1). The first item of the WUIPQ ("Did you use the Internet for pregnancy-related information during your pregnancy?”) was moved and became item 22 in the Brazilian version. The items in Section $\mathrm{G}$ of the original questionnaire were transferred to Section A of the B-WUIPQ, where items addressing color or race/ethnicity, number of children, occupation, and number of residents in the house were included. These changes were made after obtaining the agreement of the author of the original questionnaire.

A total of 151 women were recruited for the pre-test, 28 of whom (16.2\%) were excluded for not meeting the eligibility criteria. The respondents were pregnant $(84.09 \%)$ with self-declared white or brown skin color (91.43\%), on their first pregnancy (58.06\%), had access to the Internet at home (96.6\%), had a family income of one to two monthly minimum wages $(47.62 \%)$ and underwent prenatal care in the public health system (65.6\%). Regarding the structure of the questionnaire, $88.1 \%$ considered the items adequate in terms of clarity of language and pertinence to Brazilian culture. The sequence and organization of the questionnaire were rated as excellent/good (84.1\%). There were 16 comments on ten items that led to the rewriting of items 19, 32, and 63 (Box 1).

After the pre-test, the panel of experts performed the necessary adjustments, resulting in the B-WUIPQ. The item of place of residence (item 60) was excluded since only women residing in Brazil were selected. A filter question was added immediately after the informed consent form to facilitate the selection of the participants: "Are you pregnant or have you had a child less than a year ago?" Items that were changed during the cross-cultural adaptation of WUIPQ are presented in Box 2.

\section{The measurement equivalence}

The pregnant women and mothers who answered the questionnaire during the evaluation of testretest reliability $(\mathrm{n}=117)$ and internal consistency/dimensionality $(\mathrm{n}=673)$ had similar sociodemographic characteristics to the women who participated in the pre-test. The sociodemographic profile was, respectively, for pre-test and internal consistency/dimensionality samples: mean age [26.6 ( \pm 5.9$)$; $27.0( \pm 5,8)$ ], income < 2 minimum wages - USD 566,16 (51.2\%; $40 \%), 9$ to 12 years of study $(33 \% ; 21 \%)$, with black or yellow skin color (51\%; 43.5\%) and Internet access at home (96.6\%; 98.4\%).

The reliability coefficients were shown in Table 1. The ICC for B-PDMS was 0.85 (95\%CI: 0.7910.899) and most B-WUIPQ items showed substantial agreement, showing coefficient values greater than 0.60 . The Cronbach's alpha coefficient for the scale was 0.91 , with no important change if an item were removed (Table 2). The standardized factor loadings ranged from 0.46 to 0.81 (Figure 1). The CFI was 0.989, the TLI was 0.984, and the RMSEA was 0.08 (95\%CI: 0.069-0.091), indicating goodness-of-fit considering the correlations among the items on the scale (Figure 1).

\section{Discussion}

The concepts and items of the B-WUIPQ were considered relevant and acceptable to Brazilian pregnant women, and it showed satisfactory reproducibility for most variables. Few variables of B-WUIPQ (6) did not reach acceptable reproducibility. The largest number of items with kappa < 0.60 was on the frequency of searching for specific information during pregnancy (general information, treatment, and products related to pregnancy). These results may represent the inaccuracy of the measurement used, since it is difficult to accurately indicate the number of times the Internet was consulted during pregnancy. The variables about the searched source and the information quality available on the Internet also showed kappa $<0.6$. This inconsistency may be due to the fact that careful selection and evaluation of Internet content sources is not routine for most users.

The goodness-of-fit indicators (CFI, TLI, and RMSEA) of the B-PDMS were adequate, indicating that the adapted scale can be maintained. The factor loadings $>0.70$ for most items indicate that the items measure the latent variable (usefulness of the Internet in decision-making). The Q43.9 "Affected 
Box 1

Adaptations performed on items of Women's Use of the Internet in Pregnancy Questionnaire (WUIPQ) during the semantic equivalence stage.

\begin{tabular}{|c|c|c|}
\hline Steps of adaptations & WUIPQ items & Reasons for adaptations \\
\hline Synthesis & Q15/Q16/Q55/Q64 & $\begin{array}{c}\text { This professional category was removed from these items, since } \\
\text { "obstetric nurse" is not yet a widely disseminated category in the } \\
\text { Brazilian healthcare system. }\end{array}$ \\
\hline Synthesis & $\begin{array}{c}\text { Q15/Q35/Q43a/Q49a/Q51a/Q52a } \\
\text { "visit" }\end{array}$ & Original version. \\
\hline Synthesis & $\begin{array}{l}\text { Q16/Q55/Q64 } \\
\text { "health visitor"/“GP" }\end{array}$ & $\begin{array}{l}\text { In the response options for professional categories in the Irish } \\
\text { healthcare system, "health visitor" and "GP" were replaced with } \\
\text { "Community Health Agent" and "General Physician/Family Health } \\
\text { Physician", respectively, which are the categories used in the Brazilian } \\
\text { healthcare system. }\end{array}$ \\
\hline Synthesis & $\begin{array}{l}\text { Q17 and Q18 } \\
\text { [a] General search engines (e.g., } \\
\text { Yahoo, Google, MSN) } \\
\text { [b] Local health service websites } \\
\text { (e.g., NHS Health Net) }\end{array}$ & $\begin{array}{l}\text { Items } 17 \text { and } 18 \text { list sources of information available on the Internet. } \\
\text { Among the websites presented in option A, "MSN" was replaced with } \\
\text { "Bing", which is one of the three most widely used in Brazil. Option B } \\
\text { "Local health service websites, e.g., NHS Health Net" was excluded, } \\
\text { as there are no social assistance or health service websites for each } \\
\text { region of Brazil that provide information on the health services } \\
\text { offered and available establishments (hospitals, healthcare centers, } \\
\text { social services, community services and homecare services). The most } \\
\text { widely used social media (Facebook, Twitter, YouTube, Instagram and } \\
\text { WhatsApp) were added to items } 17 \text { and } 18 .\end{array}$ \\
\hline Synthesis & $\begin{array}{l}\text { Q24. How many times have you } \\
\text { used the Internet to search for } \\
\text { information about a pregnancy } \\
\text { related product (e.g., Prams, } \\
\text { maternity wear, TENS, EPI-NO)? }\end{array}$ & $\begin{array}{l}\text { Little known products among Brazilian pregnant women ("TENS and } \\
\text { EPI-NO") were replaced with products of higher demand (baby shower, } \\
\text { maternity bag and pregnant fashion). }\end{array}$ \\
\hline Synthesis & $\begin{array}{l}\text { Q58. What age are you? } \\
\text { Q66. What is the highest level of } \\
\text { education you have completed? }\end{array}$ & $\begin{array}{l}\text { Although no divergence was found between versions T1 and T2 } \\
\text { regarding the translation of item 58, it is more common in Brazil to ask } \\
\text { "Quantos anos você tem?" [How old are you?] than "What is your age?" } \\
\text { Regarding item 66, both translations were considered inadequate for } \\
\text { measuring the level of schooling of the participants according to the } \\
\text { Brazilian educational system. }\end{array}$ \\
\hline Synthesis & $\begin{array}{l}\text { Q72. Em que tipo de serviço você } \\
\text { realizou o seu pré-natal? } \\
\text { [a] Público } \\
\text { [b] Particular } \\
\text { [c] Plano de saúde/convênio } \\
\text { [d] Não realizei pré-natal }\end{array}$ & $\begin{array}{l}\text { This item was added to investigate the type of health services the } \\
\qquad \text { women used for prenatal care. }\end{array}$ \\
\hline Revision by the panel of experts & $\begin{array}{l}\text { Q7. Did you seek information from } \\
\text { the Internet during your pregnancy } \\
\text { because you were reluctant to ask } \\
\text { the health professional(s) any more } \\
\text { questions? }\end{array}$ & $\begin{array}{l}\text { The term "reluctant" was interpreted as if the respondent was fearful } \\
\text { in the sense of not feeling at ease with regards to asking a question } \\
\text { to her healthcare provider. Thus, the best option encountered to } \\
\text { interpret "reluctant" as "receosa" on the B-WUIPQ. }\end{array}$ \\
\hline Revision by the panel of experts & $\begin{array}{l}\text { Q12. Did you seek information from } \\
\text { the Internet during your pregnancy } \\
\text { because you wanted information } \\
\text { about the prognosis (outcome) of } \\
\text { a condition associated with your } \\
\text { pregnancy? }\end{array}$ & $\begin{array}{l}\text { The question regarded the concept of prognosis (outcome) translated } \\
\text { to the word for consequence. The author questioned the semantic } \\
\text { equivalence of the term (forecast). Therefore, the decision was made } \\
\text { to replace "consequence" with the expression "what might happen" to } \\
\text { facilitate the understanding of the concept of prognosis by the target } \\
\text { population. }\end{array}$ \\
\hline
\end{tabular}

(continues) 
Box 1 (continued)

\begin{tabular}{|c|c|c|}
\hline Steps of adaptations & WUIPQ items & Reasons for adaptations \\
\hline Revision by the panel of experts & $\begin{array}{l}\text { Q31. How often did you usually FIND } \\
\text { the information you needed? }\end{array}$ & $\begin{array}{l}\text { Although the term "how often" was translated as "quantas vezes" ["how } \\
\text { many times"] in both T1 and T2, the panel of experts rewrote the } \\
\text { expression as "Com que frequência" ["with what frequency"], since no } \\
\text { numerical data was provided in the response options. }\end{array}$ \\
\hline Revision by the panel of experts & $\begin{array}{l}\text { Q32*. How EASY or DIFFICULT was it } \\
\text { to find information on the INTERNET } \\
\text { on the topic you were searching? }\end{array}$ & $\begin{array}{l}\text { Translations T1 and T2 used to expression "O quão fácil ou difícil" } \\
\text { as translation for "how easy or difficult". A suggestion was made to } \\
\text { change this to "O quanto foi FÁCIL ou DIFICIL" [To what extent was it } \\
\text { EASY or DIFFICULT] to find information through the Internet on the } \\
\text { subject that you were searching? }\end{array}$ \\
\hline Revision by the panel of experts & Q59. Are you? & $\begin{array}{c}\text { This question regards the marital status of the respondent. It was } \\
\text { considered more pertinent to ask "What is your marital status?" than } \\
\text { "Are you...?". }\end{array}$ \\
\hline Revision by the panel of experts & $\begin{array}{l}\text { Q64. Which health professional(s) } \\
\text { did you attend for antenatal care } \\
\text { during your pregnancy? }\end{array}$ & $\begin{array}{l}\text { Neither option presented in the two translations was selected in the } \\
\text { consensus version. The decision was made to rewrite the item: "What } \\
\text { healthcare providers do/did you see during the prenatal period?". }\end{array}$ \\
\hline After the pretest & $\begin{array}{l}\text { Q19. When you look for PREGNANCY } \\
\text { information on the Internet, is there } \\
\text { a particular site you usually go to, } \\
\text { or do you visit or browse different } \\
\text { sites? (One favourite site/Visit } \\
\text { different sites) }\end{array}$ & $\begin{array}{l}\text { This item was rewritten considering the suggestion of a participant in } \\
\text { the pretest based on the justification that the response options were } \\
\text { contained within the question itself. }\end{array}$ \\
\hline After the pretest & $\begin{array}{l}\text { Q32. How EASY or DIFFICULT was it } \\
\text { to find information on the INTERNET } \\
\text { on the topic you were searching? }\end{array}$ & $\begin{array}{l}\text { After the suggestion to rewrite. The decision was made to replace the } \\
\text { statement of the item to facilitate the understanding of the target } \\
\text { population ("What degree of difficulty did you have in seeking the } \\
\text { information you needed on the Internet?") }\end{array}$ \\
\hline After the pretest & $\begin{array}{l}\text { Q63. Will this be OR was this your } \\
\text { first pregnancy? }\end{array}$ & $\begin{array}{l}\text { ("Is/was it your first pregnancy?") A suggestion for rewriting was made } \\
\text { ("Is or was this your first pregnancy?"). }\end{array}$ \\
\hline
\end{tabular}

Note: the changes made to the Preparation for Decision Making Scale (PDMS) were described in items 43, 49, 51 and 52.

your relationship with your primary healthcare provider" was the only one of the 11 items to have a lower factor loading (0.54), but this value was still within the acceptable limit 34 . The distribution of the answers to Q43.9 had a different pattern than that found for the other items of the B-PDMS. Two-thirds of the women (66.6\%) reported that the use of the Internet did not affect their relationship with their healthcare provider (responses of "not at all"). This finding should be evaluated considering the changes observed in the healthcare provider-patient relationship stemming from the increased access to information on the Internet 35,36 . The dissemination of information through the Internet has contributed to the individuals' empowerment regarding aspects related to the health/illness process, causing changes in the asymmetrical relationship between healthcare providers and patients 35 . The participatory attitude of an informed patient can be understood as questioning the physician's knowledge 36 , and it is often necessary for physicians to explain themselves to strengthen their conduct and counteract erroneous concepts acquired from the Internet, which can affect the healthcare providerpatient relationship. The participants' profile may have contributed to the result on Q43.9, as most of the sample was composed of women with middle to a low level of schooling and in their first pregnancy/child. Women with this profile tend to behave more passively during medical appointments, which favors the maintenance of asymmetry in the healthcare provider-patient relationship. For the other items, most of the respondents chose response options with higher scores (sometimes, often and very often). This result agrees with data described in previous studies, which state that the Internet 
Box 2

Comparison between the original questionnaire, the synthesis version and the final version of the adapted items of the Women's Use of the Internet in Pregnancy Questionnaire (WUIPQ) and presentation of the Brazilian version of Preparation for Decision Making Scale (B-PDMS).

\begin{tabular}{|c|c|c|}
\hline Original version & & \\
\hline $\begin{array}{l}\text { Q7. Did you seek information from the } \\
\text { Internet during your pregnancy because } \\
\text { you were reluctant to ask the health } \\
\text { professional(s) any more questions? (Yes/No) }\end{array}$ & $\begin{array}{l}\text { Q7. Você buscou informações da Internet durante } \\
\text { a sua gravidez porque estava resistente em fazer } \\
\text { mais alguma pergunta ao(aos) profissional(ais) de } \\
\text { saúde? (Sim/Não) }\end{array}$ & $\begin{array}{c}\text { Porque estava receosa em fazer mais perguntas } \\
\text { ao(s) profissional(ais) de saúde. (Sim/Não) }\end{array}$ \\
\hline $\begin{array}{l}\text { Q12. Did you seek information from the } \\
\text { Internet during your pregnancy because you } \\
\text { wanted information about the prognosis } \\
\text { (outcome) of a condition associated with } \\
\text { your pregnancy? (Yes/No) }\end{array}$ & $\begin{array}{c}\text { Q12. Você buscou informações da Internet } \\
\text { durante a sua gravidez, porque queria } \\
\text { informações sobre o prognóstico (consequência) } \\
\text { de uma condição associada à sua gestação? (Sim/ } \\
\text { Não) }\end{array}$ & $\begin{array}{l}\text { Porque queria informações sobre o prognóstico (o } \\
\text { que poderia acontecer) de uma condição associada } \\
\qquad \text { à sua gestação. (Sim/Não) }\end{array}$ \\
\hline $\begin{array}{l}\text { Q15. When did you identify a need to search } \\
\text { the Internet for information? (Tick all that } \\
\text { apply) } \\
\text { Before an antenatal visit } \\
\text { After an antenatal visit } \\
\text { Instead of visiting a midwife or doctor } \\
\text { Unrelated to an antenatal visit }\end{array}$ & $\begin{array}{l}\text { Q15. Quando você identificou a necessidade de } \\
\text { buscar informações da Internet? (Marque todas as } \\
\text { opções que se aplicam) } \\
\text { Antes de uma consulta de pré-natal } \\
\text { Após uma consulta pré-natal } \\
\text { Ao invés de consultar um médico } \\
\text { Sem relação com uma consulta de pré-natal }\end{array}$ & $\begin{array}{l}\text { Q24. Quando você identificou a necessidade de } \\
\text { buscar informações da Internet? (Marque todas as } \\
\text { opções que se aplicam) } \\
\text { Antes de uma consulta de pré-natal. } \\
\text { Após uma consulta de pré-natal. } \\
\text { Em vez de consultar um médico } \\
\text { Sem relação com uma consulta de pré-natal }\end{array}$ \\
\hline $\begin{array}{l}\text { Q16. Did you seek information from any of } \\
\text { the following sources before searching the } \\
\text { Internet? (Tick all that apply) } \\
\text { Midwife } \\
\text { Doctor } \\
\text { Health Visitor } \\
\text { Magazines/Newspapers } \\
\text { Leaflets/Pamplets } \\
\text { Family/Friend } \\
\text { Did not look for information from any other } \\
\text { source } \\
\text { Other: (please specify) }\end{array}$ & $\begin{array}{l}\text { Q16. Você buscou informações de alguma das } \\
\text { seguintes fontes antes de pesquisar na Internet? } \\
\text { (Marque todas as opções que se aplicam) } \\
\text { Médico } \\
\text { Agente comunitária de saúde } \\
\text { Revistas/Jornais } \\
\text { Cartilhas/panfletos } \\
\text { Família/Amigo } \\
\text { Não busquei informações de nenhuma outra fonte } \\
\text { Outros: (especifique, por favor) }\end{array}$ & $\begin{array}{l}\text { Q25. Você buscou informações de alguma das } \\
\text { seguintes fontes ANTES de pesquisar na Internet? } \\
\text { (Marque todas as opções que se aplicam) } \\
\text { Médico } \\
\text { Agente comunitário de saúde } \\
\text { Revistas/Jornais } \\
\text { Cartilhas/panfletos } \\
\text { Família/Amigo(a) } \\
\text { Não busquei informações de nenhuma outra fonte } \\
\text { Outro (especifique) }\end{array}$ \\
\hline $\begin{array}{l}\text { Q17. The following are resources available } \\
\text { free via the Internet. For each resource } \\
\text { below: Tick } 1 \text { = If you have USED this specific } \\
\text { resource or } 2 \text { = If you have NOT USED the } \\
\text { resource during your pregnancy. } \\
\text { [a] General search engine e.g. Yahoo, Google, } \\
\text { MSN } \\
\text { [b] Local health service websites e.g. NHS } \\
\text { Health Net } \\
\text { [c] Government websites e.g. DOH } \\
\text { (Department of Health) } \\
\text { [d] Links to Medical Journals e.g. PubMed/ } \\
\text { MEDLINE } \\
\text { [e] Websites run by health professional }\end{array}$ & $\begin{array}{l}\text { Q18. As seguintes fontes estão disponíveis } \\
\text { gratuitamente na Internet. Para cada fonte abaixo: } \\
\text { Marque } 1 \text { = Se você USOU esta fonte, ou } 2 \text { = Se } \\
\text { você NÃO USOU a fonte durante a sua gravidez. } \\
\text { [a] Site de busca, por exemplo, Google, Yahoo, } \\
\text { Bing } \\
\text { [b] Sites governamentais (Secretaria Municipal, } \\
\text { Estadual ou do Ministério de Saúde) } \\
\text { [c] Links para revistas médicas, como, por } \\
\text { exemplo, SciELO, LILACS, Bireme } \\
\text { [d] Sites mantidos por profissionais de saúde } \\
\text { [e] Mídias sociais: Facebook, Twiter, YouTube, } \\
\text { Instagram, WhatsApp) }\end{array}$ & $\begin{array}{l}\text { Q26. As seguintes fontes estão disponíveis } \\
\text { gratuitamente na Internet. Para cada fonte abaixo: } \\
\text { Marque } 1 \text { = Se você USOU esta fonte, ou } 2 \text { = Se você } \\
\text { NÃO USOU a fonte durante a sua gravidez. } \\
\text { [a] Site de busca, por exemplo, Google, Yahoo, Bing } \\
\text { [b] Sites governamentais (Secretaria Municipal, } \\
\text { Estadual ou do Ministério de Saúde) } \\
\text { [c] Links para revistas médicas, como, por } \\
\text { exemplo, SciELO, LILACS, Bireme } \\
\text { [d] Sites mantidos por profissionais de saúdel } \\
\text { hospitais/maternidades } \\
\text { [e] Mídias sociais: Facebook, Twitter, YouTube, } \\
\text { Instagram e WhatsApp }\end{array}$ \\
\hline
\end{tabular}

(continues) 


\begin{tabular}{l}
\hline Original version \\
\hline Q18. For each resource below: Tick 1 = if you \\
TRUST the information from that source; 2 = \\
if you DO NOT TRUST the information from \\
that source or 3 = DON'T KNOW \\
[a] General search engine e.g. Yahoo, Google, \\
MSN
\end{tabular}

[b] Local health service websites e.g. NHS Health Net

[c] Government websites e.g. DOH

(Department of Health)

[d] Links to medical journals e.g. PubMed/ MEDLINE

[e] Websites run by health professional Q19 When you look for PREGNANCY information on the Internet, is there a particular website you usually go to, or do you visit or browse different websites? (One favorite website/ Visit different websites) Q24. How many times have you used the Internet to search for information about a pregnancy related product (e.g. Prams, Maternity wear, TENS, EPI-NO)? (Never/1-5 times/6-10 times/More than 10 times) Q31. How often did you usually FIND the information you needed? (Always/Most of the time/Only sometimes/Hardly ever/Never)

Q32. How EASY or DIFFICULT was it to find information on the INTERNET on the topic you were searching? (Very easy/Somewhat easy/Somewhat difficult/Very difficult/Don't know)

Q42a. To what extent did the use of the Internet for information help you to identify questions you wanted to ask a health professional? (Not at all/Very little/ Somewhat/Quite a bit/A great deal) Q43a. To what extent did the use of the Internet for information prepare you for your next antenatal visit? (Not at all/Very little/ Somewhat/Quite a bit/A great deal) Q44a. To what extent did the use of the Internet for information help you to be involved in the decision making process as you wanted? (Not at all/Very little/Somewhat/ Quite a bit/A great deal)

Q45a. To what extent did the use of the Internet for information help you make a better decision? (Not at all/Very little/ Somewhat/Quite a bit/A great deal)

\section{Synthesis version T1.2}

Q18. Para cada fonte abaixo: Marque 1 = se você CONFIA nas informações desta fonte; 2 = se você NÃO CONFIA nas informações desta fonte, ou 3 = Se não sabe

[a] Site de busca, por exemplo, Google, Yahoo, Bing

[b] Sites governamentais (Secretaria Municipal, Estadual ou do Ministério de Saúde)

[c] links para revistas médicas, como, por exemplo, SCIELO, LILACS, Bireme

[d] Sites mantidos por profissionais de saúde [e] Mídias sociais: Facebook, Twiter, YouTube, Instagram e WhatsApp

Q19. Quando você busca informações sobre GRAVIDEZ na Internet, você geralmente visita um site específico, ou visita/navega por vários sites? (Um site favorito/Visito vários sites)

Q24. Quantas vezes você usou a Internet para buscar informações sobre um produto relacionado à gravidez (por exemplo, enxoval do bebê, mala da maternidade, moda gestante? (NUNCA/1-5 vezes/6-10 vezes/Mais de 10 vezes)

Q31. Quantas vezes você geralmente encontrou as informações que você precisava? (Sempre) Frequentemente/Às vezes/Raramente/Nunca)

Q32. O quão FÁCIL ou DIFÍCIL foi encontrar informações pela Internet sobre o assunto que você estava procurando? (Muito fácil/Um pouco fácil/Um pouco difícil/Muito difícil/Não sei)

Q42. Até que ponto o uso da Internet na busca por informações ajudou a identificar itens que você queria perguntar a um profissional de saúde? (Nunca/Muito Pouco/Às vezes/Muito/Bastante)

Q43. Até que ponto o uso da Internet na busca por informações preparou você para sua próxima consulta de pré-natal? (Nunca/Muito Pouco/ Às vezes/Muito/Bastante)

Q44. Até que ponto o uso da Internet na busca por informações ajudou a se envolver no processo de tomada de decisões que você desejava? (Nada/ Muito pouco/Às vezes/Muito/Bastante)

Q45. Até que ponto o uso da Internet na busca por informações ajudou você a tomar uma decisão melhor? (Nada/Muito pouco/Às vezes/ Muito/Bastante)

\section{Final version}

Q27. Para cada fonte abaixo: Marque 1 = se você CONFIA nas informações desta fonte; 2 = se você NÃO CONFIA nas informações desta fonte, ou $3=$ Se NÃO SABE

[a] Site de busca, por exemplo, Google, Yahoo, Bing

[b] Sites governamentais (Secretaria Municipal, Estadual ou do Ministério de Saúde)

[c] Links para revistas médicas, como, por exemplo, SCIELO, LILACS, Bireme

[d] Sites mantidos por profissionais de saúdel maternidades

[e] Mídias sociais: Facebook, Twitter, YouTube, Instagram e WhatsApp)

Q28. Quando você buscou informações sobre GRAVIDEZ na Internet, como você fez?

Navegou/Visitou um site favorito Navegou/Visitou vários sites

Q30. Quantas vezes você usou a Internet para: buscar informações sobre um produto relacionado à gravidez (p.ex.: enxoval do bebê, mala da maternidade, moda gestante)? (Nunca/1 a 5 vezes/6 a 10 vezes/Mais de 10 vezes)

Q32. Com que frequência você geralmente encontrou as informações que você precisava? (Sempre/Frequentemente/Às vezes/Raramentel Nunca)

Q33. Que grau de dificuldade você teve ao buscar as informações que precisava na Internet? (Muito fácil/Um pouco fácil/Um pouco difícil/Muito difícil/Não sei)

Q43.1. Até que ponto o uso da Internet na busca por informações...

ajudou a identificar itens que você queria perguntar a um profissional de saúde? (Nuncal Muito Pouco/Às vezes/Muito/Bastante)

Q43.2. preparou você para sua próxima consulta de pré-natal? (Nunca/Muito Pouco/Às vezes/ Muito/Bastante)

Q43.3. Ajudou você a se envolver no processo de tomada de decisões que você desejava? (Nunca/ Muito Pouco/Às vezes/Muito/Bastante)

Q43.4. Ajudou você a tomar uma decisão melhor? (Nunca/Muito Pouco/Às vezes/Muito/Bastante) 
Box 2 (continued)

\begin{tabular}{|c|c|c|}
\hline & Synthesis version T1.2 & \\
\hline $\begin{array}{l}\text { Q46a. To what extent did the use of the } \\
\text { Internet for information help your health } \\
\text { professional(s) be more aware of your } \\
\text { questions and concerns? (Not at all/Very } \\
\text { little/Somewhat/Quite a bit/A great deal) }\end{array}$ & $\begin{array}{l}\text { Q46. Até que ponto o uso da Internet na busca } \\
\text { por informações contribuiu para que seu(s) } \\
\text { profissional(ais) de saúde ficassem mais ciente(s) } \\
\text { das suas dúvidas e preocupações? (Nada/Muito } \\
\text { pouco/Às vezes/Muito/Bastante) }\end{array}$ & $\begin{array}{l}\text { Q43.5. Contribuiu para que seu(s) profissional(ais) } \\
\text { de saúde ficasse(em) mais ciente(s) das suas } \\
\text { dúvidas e preocupações? (Nunca/Muito Pouco/ } \\
\text { Às vezes/Muito/Bastante) }\end{array}$ \\
\hline $\begin{array}{l}\text { Q47a. To what extent did the use of the } \\
\text { Internet for information help give you } \\
\text { more control over decisions affecting your } \\
\text { pregnancy? (Not at all/Very little/Somewhat/ } \\
\text { Quite a bit/A great deal) }\end{array}$ & $\begin{array}{l}\text { Q47. Até que ponto o uso da Internet na busca por } \\
\text { informações ajudou você a ter mais controle sobre } \\
\text { as decisões que afetavam a sua gravidez? (Nada/ } \\
\text { Muito pouco/Às vezes/Muito/Bastante) }\end{array}$ & $\begin{array}{l}\text { Q43.6. Ajudou você a ter mais controle sobre as } \\
\text { decisões que afetavam a sua gravidez? (Nunca/ } \\
\text { Muito Pouco/Às vezes/Muito/Bastante) }\end{array}$ \\
\hline $\begin{array}{l}\text { Q48a. To what extent did the use of the } \\
\text { Internet for information help your lead } \\
\text { health professional understand your } \\
\text { preferences for involvement in the decision } \\
\text { making process? (Not at all/Very little/ } \\
\text { Somewhat/Quite a bit/A great deal) }\end{array}$ & $\begin{array}{l}\text { Q48. Até que ponto o uso da Internet na busca por } \\
\text { informações ajudou o seu profissional de saúde } \\
\text { a compreender suas preferências no processo de } \\
\text { tomada de decisões? (Nada/Muito pouco/Às vezes/ } \\
\text { Muito/Bastante) }\end{array}$ & $\begin{array}{l}\text { Q43.7. Ajudou o seu profissional de saúde a } \\
\text { compreender suas preferências no processo de } \\
\text { tomada de decisões? (Nunca/Muito Pouco/Às vezes/ } \\
\text { Muito/Bastante) }\end{array}$ \\
\hline $\begin{array}{l}\text { Q49a. To what extent did the use of the } \\
\text { Internet for information make the follow up } \\
\text { antenatal visit run more smoothly? (Not at } \\
\text { all/Very little/Somewhat/Quite a bit/A great } \\
\text { deal) }\end{array}$ & $\begin{array}{c}\text { Q49. Até que ponto o uso da Internet na busca por } \\
\text { informações fez com que a consulta de pré-natal } \\
\text { ocorresse mais facilmente? (Nada/Muito pouco/Às } \\
\text { vezes/Muito/Bastante) }\end{array}$ & $\begin{array}{c}\text { Q43.8. Fez com que a consulta de pré-natal } \\
\text { ocorresse mais facilmente? (Nunca/Muito Pouco/Às } \\
\text { vezes/Muito/Bastante) }\end{array}$ \\
\hline $\begin{array}{l}\text { Q50a. To what extent did the } 4 \\
\text { the Internet for information af } \\
\text { relationship with with your lea } \\
\text { professional? (Not at all/Very li } \\
\text { Somewhat/Quite a bit/A great }\end{array}$ & $\begin{array}{l}\text { Q50. Até que ponto o uso da Internet na busca } \\
\text { por informações afetou sua relação com o seu } \\
\text { principal profissional de saúde? (Nada/Muito } \\
\text { pouco/Às vezes/Muito/Bastante) }\end{array}$ & $\begin{array}{c}\text { Q43.9. Afetou sua relação com o seu principal } \\
\text { profissional de saúde? (Nunca/Muito Pouco/Às } \\
\text { vezes/Muito/Bastante) }\end{array}$ \\
\hline $\begin{array}{l}\text { Q51a. To what extent did the use of the } \\
\text { Internet for information improve the } \\
\text { way time was spent during the follow- } \\
\text { up antenatal visit? (Not at all/Very little/ } \\
\text { Somewhat/Quite a bit/A great deal) }\end{array}$ & $\begin{array}{l}\text { Q51. Até que ponto o uso da Internet na busca } \\
\text { por informações melhorou a forma como o tempo } \\
\text { foi gasto durante as suas consultas de pré-natal? } \\
\text { (Nada/Muito pouco/Às vezes/Muito/Bastante) }\end{array}$ & $\begin{array}{c}\text { Q43.10. Melhorou a forma como o tempo foi gasto } \\
\text { durante as suas consultas de pré-natal? (Nuncal } \\
\text { Muito Pouco/Às vezes/Muito/Bastante) }\end{array}$ \\
\hline $\begin{array}{l}\text { Q52a. To what extent did the use of the } \\
\text { Internet for information improve the quality } \\
\text { of the follow-up antenatal visit? (Not at all/ } \\
\text { Very little/Somewhat/Quite a bit/A great deal) }\end{array}$ & $\begin{array}{l}\text { Q52. Até que ponto o uso da Internet na busca } \\
\text { por informações melhorou a qualidade das suas } \\
\text { consultas de pré-natal? (Nada/ } \\
\text { Muito pouco/Às vezes/Muito/Bastante) }\end{array}$ & $\begin{array}{l}\text { Q43.11. Melhorou a qualidade das suas consultas } \\
\text { de pré-natal? (Nunca/Muito Pouco/ } \\
\text { Às vezes/Muito/Bastante) }\end{array}$ \\
\hline $\begin{array}{l}\text { Q55. Did you discuss the information } \\
\text { you found on the Internet with any of the } \\
\text { following? (1=YES; } 2=\mathrm{NO} \text { ) } \\
\text { [a] Midwife } \\
\text { [b] Obstetrician } \\
\text { [c] GP } \\
\text { [d] Health visitor } \\
\text { [e] Dentist } \\
\text { [f] Pharmacist } \\
\text { [g] Physiotherapist } \\
\text { [h] Husband/Partner } \\
\text { [i] Relative } \\
\text { [j] Friend }\end{array}$ & $\begin{array}{l}\text { Q55. Você conversou sobre as informações que } \\
\text { encontrou na Internet com as seguintes pessoas? } \\
\qquad(1=\mathrm{SIM} ; 2=\mathrm{NÃO}) \\
\text { [a] Obstetra } \\
\text { [b] Médico generalista/Médico da saúde da família } \\
\text { [c] Agente comunitário de saúde } \\
\text { [d] Dentista } \\
\text { [e] Farmacêutico(a) } \\
\text { [f] Fisioterapeuta } \\
\text { [g] Marido/Parceiro(a) } \\
{[\mathrm{h}] \text { Parente }} \\
{[\mathrm{i}] \text { Amigo(a) }}\end{array}$ & $\begin{array}{l}\text { Q46. Você conversou sobre as informações que } \\
\text { encontrou na Internet com as seguinte pessoas? } \\
\qquad(1=\text { SIM; } 2=N \text { ÃO) } \\
\text { [a] Obstetra } \\
\text { [b] Médico generalista/Médico da saúde da família } \\
\text { [c] Agente comunitário de saúde } \\
\text { [d] Dentista } \\
\text { [e] Farmacêutico(a) } \\
\text { [f] Fisioterapeuta } \\
{[\mathrm{g}] \text { Marido/Parceiro(a) }} \\
{[\mathrm{h}] \text { Parente }} \\
{[\mathrm{i}] \text { Amigo(a) }}\end{array}$ \\
\hline
\end{tabular}

(continues) 
Box 2 (continued)

\begin{tabular}{|c|c|c|}
\hline Original version & Synthesis version T1.2 & Final version \\
\hline Q58. What age are you? & Q58. Quantos anos você tem? & Q3. Quantos anos você tem? \\
\hline $\begin{array}{l}\text { Q59. Are You? } \\
\text { Married } \\
\text { Single } \\
\text { Single but in steady relationship } \\
\text { Divorced } \\
\text { Separated } \\
\text { Widow }\end{array}$ & $\begin{array}{l}\text { Q59. Você é? } \\
\text { Solteira } \\
\text { Casada } \\
\text { União estável } \\
\text { Divorciada } \\
\text { Separada } \\
\text { Viúva }\end{array}$ & $\begin{array}{l}\text { Q4. Qual é o seu estado civil? } \\
\text { Solteira } \\
\text { Casada } \\
\text { União estável } \\
\text { Divorciada } \\
\text { Separada } \\
\text { Viúva }\end{array}$ \\
\hline \multirow[t]{5}{*}{ Q60. Where do you live? (Select from the list) } & Q60. Onde você mora? (Escolha da lista) & Excluded \\
\hline & & $\begin{array}{c}\text { Q5**. Qual é a sua cor ou raça/etnia? } \\
\text { Branca } \\
\text { Parda } \\
\text { Preta } \\
\text { Amarela } \\
\text { Raça/Etnia Indígena }\end{array}$ \\
\hline & & $\begin{array}{c}\text { Q6**. Em que área você trabalha? } \\
\text { Trabalha no setor formal } \\
\text { Trabalha no setor informal (sem carteira assinada) } \\
\text { Trabalha por conta própria } \\
\text { Trabalha em casa (costura, cozinha, aulas } \\
\text { particulares...) } \\
\text { Do lar/Dona de casa } \\
\text { Desempregada } \\
\text { Estudante } \\
\text { Aposentada }\end{array}$ \\
\hline & & $\begin{array}{l}\text { Q7. Quantas pessoas, incluindo você, moram na } \\
\text { sua casa? }\end{array}$ \\
\hline & & 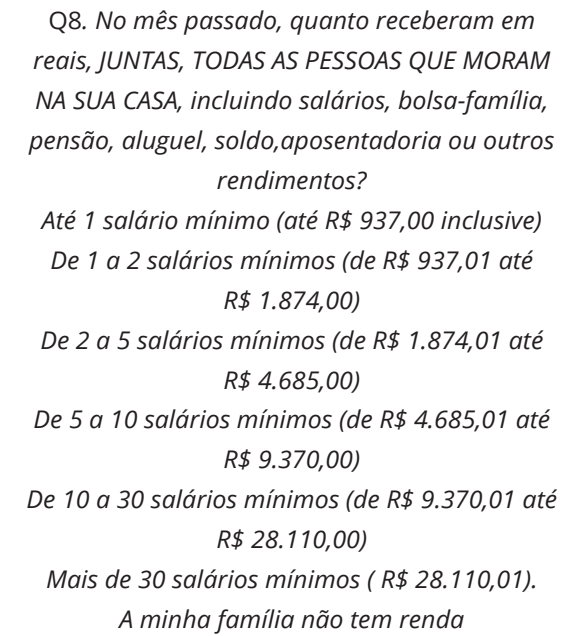 \\
\hline
\end{tabular}

(continues) 
Box 2 (continued)

\begin{tabular}{|c|c|c|}
\hline Original version & Synthesis version T1.2 & Final version \\
\hline \multirow[t]{2}{*}{$\begin{array}{l}\text { Q63. Will this be OR was this your first } \\
\text { pregnancy? (Yes/No) }\end{array}$} & Q63. É/Foi a sua primeira gravidez? (Sim/Não) & $\begin{array}{l}\text { Q12. Esta é ou foi a sua primeira gravidez? } \\
\text { (Sim/Não) }\end{array}$ \\
\hline & & Q13. Quantos filhos você já tem? \\
\hline $\begin{array}{l}\text { Q64. Which health professional(s) did } \\
\text { you attend for antenatal care during your } \\
\text { pregnancy? } \\
\text { Midwife only } \\
\text { General practicioner (GP) only } \\
\text { Consultant obstetrician only } \\
\text { Midwife and GP } \\
\text { Midwife and consultant obstetrician } \\
\text { Gp and consultant obstetrician } \\
\text { Midwife, GP and consultant obstetrician } \\
\text { Did not attend any health professional for } \\
\text { antenatal care }\end{array}$ & $\begin{array}{l}\text { Q64. Qual(is) profissional(ais) de saúde você } \\
\text { consultou no pré-natal? } \\
\text { Apenas médico generalista ou médico saúde da } \\
\text { família ou obstetra ou clínico geral } \\
\text { Enfermeira e médico generalista ou médico saúde } \\
\text { da família ou obstetra ou clínico geral } \\
\text { Apenas enfermeira } \\
\text { Não procurei nenhum profissional de saúde para } \\
\text { consulta de pré-natal }\end{array}$ & $\begin{array}{l}\text { Q14. Qual(is) profissional(ais) de saúde você } \\
\text { consulta/consultou durante o pré-natal? } \\
\text { Apenas médico generalista ou médico saúde da } \\
\text { família ou obstetra ou clínico geral } \\
\text { Enfermeira e médico generalista ou médico saúde } \\
\text { da família ou obstetra ou clínico geral } \\
\text { Apenas enfermeira } \\
\text { Não procurei nenhum profissional de saúde para } \\
\text { consulta de pré-natal }\end{array}$ \\
\hline $\begin{array}{l}\text { Q66. What is the highest level of education } \\
\text { you have completed? } \\
\text { Primary school } \\
\text { Grammar/Secondary/High School } \\
\text { Technical college/Diploma } \\
\text { Undergraduate degree (associate or } \\
\text { bacholers) } \\
\text { Postgraduate degree (e.g., PGCert, PGDip, } \\
\text { MSc, PhD) } \\
\text { Other: (please specify) }\end{array}$ & $\begin{array}{l}\text { Q66. Qual é o seu nível de escolaridade? } \\
\text { Ensino Fundamental incompleto } \\
\text { Ensino fundamental completo } \\
\text { Ensino Médio incompleto } \\
\text { Ensino Médio completo } \\
\text { Superior incompleto } \\
\text { Superior completo } \\
\text { Pós-graduação } \\
\text { Outro (especifique) }\end{array}$ & $\begin{array}{l}\text { Q9. Qual é o seu nível de escolaridade? } \\
\text { Ensino Fundamental incompleto } \\
\text { Ensino Fundamental completo } \\
\text { Ensino Médio incompleto } \\
\text { Ensino Médio completo } \\
\text { Superior incompleto } \\
\text { Superior completo } \\
\text { Pós-graduação } \\
\text { Outro (especifique) }\end{array}$ \\
\hline & $\begin{array}{c}\text { Q72. Em que tipo de serviço você realizou o seu } \\
\text { pré-natal? } \\
\text { Público } \\
\text { Particular } \\
\text { Particular e plano de saúde/convênio } \\
\text { Plano de saúde/convênio } \\
\text { Não fiz/faço pré-natal }\end{array}$ & $\begin{array}{c}\text { Q16**. Em que tipo de sistema de saúde você } \\
\text { realiza/realizou seu pré-natal? } \\
\text { Público } \\
\text { Particular } \\
\text { Particular e plano de saúde/convênio } \\
\text { Plano de saúde/convênio } \\
\text { Não fiz/faço pré-natal }\end{array}$ \\
\hline
\end{tabular}

Note: PDMS scale Q42 to Q52. 
Table 1

Reliability coefficients for the Brazilian version of Women's Use of the Internet in Pregnancy Questionnaire (B-WUIPQ) items.

\begin{tabular}{|c|c|c|c|}
\hline Variables & Agreement coefficients & Value & Percent agreement \\
\hline \multicolumn{4}{|l|}{ Sociodemographic } \\
\hline Pregnant women or mothers of children less than one year of age & Simple kappa & 1.00 & 1.00 \\
\hline How old are you? & ICC & 0.99 & - \\
\hline Are you? (Marital status) & Kappa & 0.90 & 94.02 \\
\hline Skin color or race/ethnicity & Kappa & 0.97 & 98.29 \\
\hline Employment & Kappa & 0.87 & 89.74 \\
\hline Family income & ICC & 0.93 & - \\
\hline How many people, including you, live at your home? & ICC & 0.93 & - \\
\hline What is your level of schooling? & Weighted kappa & 0.88 & 91.45 \\
\hline Are you pregnant? & Kappa & 0.95 & 98.29 \\
\hline \multicolumn{4}{|l|}{ Internet use by women during pregnancy } \\
\hline If you are pregnant, how many MONTHS are you? & ICC & 0.98 & - \\
\hline Is/was it your first pregnancy? & Kappa & 0.98 & 99.15 \\
\hline How many children do you already have? & ICC & 0.93 & - \\
\hline What health professional(s) did you consult in the prenatal period? & Kappa & 0.64 & 81.20 \\
\hline How would you best describe your pregnancy? & Kappa & 0.86 & 93.16 \\
\hline At what type of service did you undergo your prenatal checkups? & Kappa & 0.76 & 86.32 \\
\hline Do YOU have access to the Internet at home? & Kappa & 1.00 & 1.00 \\
\hline $\begin{array}{l}\text { Have you ever had any formal training on accessing information on the } \\
\text { Internet? }\end{array}$ & Kappa & 0.68 & 85.47 \\
\hline Do YOU have access to the Internet at your work? & Kappa & 0.87 & 93.16 \\
\hline $\begin{array}{l}\text { Your access to the Internet during your pregnancy occurred MAINLY (home, } \\
\text { work, friend's house, other) }\end{array}$ & Kappa & 0.81 & 97.44 \\
\hline How do you classify your skill in using the Internet? & Kappa & 0.77 & 88.03 \\
\hline $\begin{array}{l}\text { Did you use the Internet to search for information related to pregnancy } \\
\text { during your pregnancy? }\end{array}$ & Kappa & 1.00 & 1.00 \\
\hline \multicolumn{4}{|l|}{ Reasons to use informations from the Internet during pregnancy } \\
\hline $\begin{array}{l}\text { Did you search for information on the Internet during your pregnancy } \\
\text { because? * }\end{array}$ & ICC & 0.72 & - \\
\hline When did you identify the need to search for information on the Internet? ** & ICC & 0.61 & - \\
\hline \multicolumn{4}{|l|}{ Selecting the Internet as source for information during the pregnancy } \\
\hline $\begin{array}{l}\text { Did you search for information from any of the following sources prior to } \\
\text { searching the Internet? } * \star \star\end{array}$ & ICC & 0.66 & - \\
\hline \multicolumn{4}{|l|}{$\begin{array}{l}\text { The following sources are available for free on the Internet. For each source } \\
\text { below: Mark } 1 \text { = If you USED this source, or } 2 \text { = If you DID NOT USE the } \\
\text { source during your pregnancy }\end{array}$} \\
\hline Search website, such as Google, Yahoo, Bing & Карра/PABAK & $0.49 / 0.96$ & 98.29 \\
\hline Government websites (Municipal, State Secretary or Ministry of Health) & Карра/PABAK & $0.65 / 0.70$ & 85.47 \\
\hline Links to medical journals, such as SciELO, LILACS, Bireme & Kappa/PABAK & $0.63 / 0.82$ & 91.45 \\
\hline Websites maintained by health professionals & Kappa/PABAK & $0.61 / 0.70$ & 80.34 \\
\hline Social media: Facebook, Twitter, YouTube, Instagram & Kappa & 0.71 & 97.44 \\
\hline \multicolumn{4}{|l|}{$\begin{array}{l}\text { For each source below: Mark } 1 \text { = if you TRUST the information from this } \\
\text { source; } 2 \text { = if you DO NOT TRUST the information from this source }\end{array}$} \\
\hline Search website, such as Google, Yahoo, Bing & Kappa & 0.84 & 97.62 \\
\hline Government websites (Municipal, State Secretary or Ministry of Health) & Карра/РABAK & $0.55 / 0.90$ & 95.38 \\
\hline Links to medical journals, such as SciELO, LILACS, Bireme & Kappa & 0.76 & 93.10 \\
\hline Websites maintained by health professionals & Карра/РABAK & $0.48 / 0.94$ & 97.01 \\
\hline Social media: Facebook, Twitter, YouTube, Instagram & Kappa & 0.84 & 93.33 \\
\hline
\end{tabular}

(continues) 
Table 1 (continued)

\begin{tabular}{|c|c|c|c|}
\hline Variables & Agreement coefficients & Value & Percent agreement \\
\hline $\begin{array}{l}\text { When you search for information about PREGNANCY on the Internet, do you } \\
\text { generally visit a specific website or do you visit/surf several websites? }\end{array}$ & Карра/РABAK & $0.39 / 0.86$ & 93.16 \\
\hline $\begin{array}{l}\text { Do you think that health professionals should suggest Internet websites } \\
\text { where pregnant women could find relevant information on their pregnancy? }\end{array}$ & Kappa/PABAK & $0.31 / 0.93$ & 96.58 \\
\hline \multicolumn{4}{|l|}{ Searching for specific information on the Internet } \\
\hline $\begin{array}{l}\text { How often did you use the Internet to search for general information on } \\
\text { pregnancy-related health? }\end{array}$ & Weighted kappa & 0.43 & 86.11 \\
\hline $\begin{array}{l}\text { How often did you use the Internet to search for information about a specific } \\
\text { condition associated with your pregnancy? }\end{array}$ & Weighted kappa & 0.66 & 88.98 \\
\hline $\begin{array}{l}\text { How often did you use the Internet to search for information about a } \\
\text { treatment indicated for you during your pregnancy? }\end{array}$ & Weighted kappa & 0.57 & 88.03 \\
\hline $\begin{array}{l}\text { How often did you use the Internet to search for information about a } \\
\text { pregnancy-related product (such as, baby shower, maternity luggage, } \\
\text { pregnancy outfits)? }\end{array}$ & Weighted kappa & 0.52 & 92.97 \\
\hline How often did you use the Internet to seek a second opinion? & Weighted kappa & 0.65 & 91.17 \\
\hline $\begin{array}{l}\text { How often did you use the Internet to participate in a discussion group with } \\
\text { other pregnant women? }\end{array}$ & Weighted kappa & 0.66 & 89.36 \\
\hline How often did you use the Internet to buy items for your pregnancy? & Weighted kappa & 0.67 & 88.98 \\
\hline $\begin{array}{l}\text { How often did you use the Internet to participate in an online support } \\
\text { group? }\end{array}$ & Weighted kappa & 0.66 & 88.60 \\
\hline $\begin{array}{l}\text { How often did you use the Internet during your pregnancy to present } \\
\text { information to a health professional? }\end{array}$ & Weighted kappa & 0.53 & 88.13 \\
\hline \multicolumn{4}{|l|}{ Gathering information from the Internet during pregnancy } \\
\hline How often did you generally find the information you needed? & Weighted kappa & 0.64 & 94.21 \\
\hline $\begin{array}{l}\text { How EASY or DIFFICULT was it to find information on the Internet about the } \\
\text { subject you were searching? }\end{array}$ & Weighted kappa & 0.76 & 96.68 \\
\hline $\begin{array}{l}\text { When gathering information from the Internet during your pregnancy, did } \\
\text { you keep a health website in your "favorites" or save it so that you could } \\
\text { return to it regularly? }\end{array}$ & Kappa & 0.69 & 84.62 \\
\hline $\begin{array}{l}\text { When gathering information from the Internet during your pregnancy, } \\
\text { did you ever know what company or organization was providing the } \\
\text { information? }\end{array}$ & Kappa & 0.51 & 76.07 \\
\hline $\begin{array}{l}\text { When gathering information from the Internet during your pregnancy, did } \\
\text { you even print out or take the information to a prenatal checkup? }\end{array}$ & Kappa/PABAK & $0.49 / 0.76$ & 88.03 \\
\hline \multicolumn{4}{|l|}{$\begin{array}{l}\text { Evaluating the information retrieved from the Internet during } \\
\text { pregnancy }\end{array}$} \\
\hline $\begin{array}{l}\text { How much did you believe the health information about PREGNANCY on the } \\
\text { Internet? }\end{array}$ & ICC & 0.70 & - \\
\hline $\begin{array}{l}\text { Did you ever visit any pregnancy website and think that some of the } \\
\text { information was wrong or misleading? }\end{array}$ & Kappa & 0.19 & 69.23 \\
\hline $\begin{array}{l}\text { How would you assess the quality of information that you obtained from the } \\
\text { Internet? }\end{array}$ & Weighted kappa & 0.83 & 94.30 \\
\hline $\begin{array}{l}\text { Do you know that there are quality indicators for assessing health } \\
\text { information on the Internet? }\end{array}$ & Kappa & 0.64 & 94.87 \\
\hline In general, how useful was the information you found on the Internet? & Kappa & 1.00 & 1.00 \\
\hline
\end{tabular}

(continues) 
Table 1 (continued)

\begin{tabular}{|c|c|c|c|}
\hline Variables & Agreement coefficients & Value & Percent agreement \\
\hline \multicolumn{4}{|l|}{$\begin{array}{l}\text { Use of the information you found on the Internet and if it had any } \\
\text { effect on your decisions about your pregnancy }\end{array}$} \\
\hline Preparation for Decision Making Scale & ICC & 0.85 & - \\
\hline $\begin{array}{l}\text { On a scale of } 0 \text { to } 10 \text {, please, indicate how confident you were in making } \\
\text { decisions regarding your pregnancy BEFORE searching for information on } \\
\text { the Internet? }\end{array}$ & ICC & 0.69 & - \\
\hline $\begin{array}{l}\text { On a scale of } 0 \text { to } 10 \text {, please, indicate how confident you were in making } \\
\text { decisions regarding your pregnancy AFTER searching for information on the } \\
\text { Internet? }\end{array}$ & ICC & 0.74 & - \\
\hline $\begin{array}{l}\text { Did you talk about the information that you found on the Internet with the } \\
\text { following people?\# }\end{array}$ & ICC & 0.76 & - \\
\hline $\begin{array}{l}\text { If you talked about information that you obtained from the Internet with a } \\
\text { HEALTH PROFESSIONAL, how did he/she react? }\end{array}$ & Kappa & 0.631 & 70.94 \\
\hline $\begin{array}{l}\text { Did the information you found on the Internet influence your opinion about } \\
\text { the way to conduct your pregnancy/delivery? }\end{array}$ & Kappa & 0.64 & 78.63 \\
\hline
\end{tabular}

ICC: intraclass correlation coefficient; PABAK: prevalence-adjusted bias-adjusted kappa.

* The ICC was obtained considering the number of affirmative answers to questions on the reasons to use the Internet;

** The ICC was obtained considering the number of affirmative answers to questions on the need to search for information on the Internet;

*** The ICC was obtained considering the number of affirmative answers to questions on the source of search for information prior to searching the Internet;

\# The ICC was obtained considering the number of affirmative answers to questions on which people do pregnant women talk about regarding

information found on the Internet.

\section{Table 2}

Cronbach's alpha coefficient for scores on the Brazilian version of Preparation for Decision Making Scale (B-PDMS) if the item were removed. Study of internal consistency $(n=117)$, Brazil, 2018.

Até que ponto o uso da Internet na busca por informações...

Q43.1....ajudou a identificar itens que você queria perguntar a um profissional de saúde? 0.91

Q43.2. ...preparou você para sua próxima consulta de pré-natal? $\quad 0.90$

Q43.3. ...ajudou você a se envolver no processo de tomada de decisões que desejava? 0.90

Q43.4. ...ajudou você a tomar uma decisão melhor? $\quad 0.89$

Q43.5. ...contribuiu para que seu(s) profissional(ais) de saúde ficasse(em) mais ciente(s) das 0.90

suas dúvidas e preocupações?

Q43.6. ....judou você a ter mais controle sobre as decisões que afetavam a sua gravidez? $\quad 0.90$

Q43.7. ...ajudou o seu profissional de saúde a compreender suas preferências no processo de 0.90

tomada de decisões?

Q43.8. ...fez com que a consulta de pré-natal ocorresse mais facilmente? $\quad 0.90$

Q43.9. ....afetou sua relação com o seu principal profissional de saúde? 0.91

Q43.10....melhorou a forma como o tempo foi gasto durante as suas consultas de pré-natal? 0.90

Q43.11....melhorou a qualidade das suas consultas de pré-natal? 0.90 
Figure 1

Factor loadings of items on the Brazilian version of the Preparation for Decision Making Scale (B-PDMS) and correlations obtained through confirmatory factor analysis.

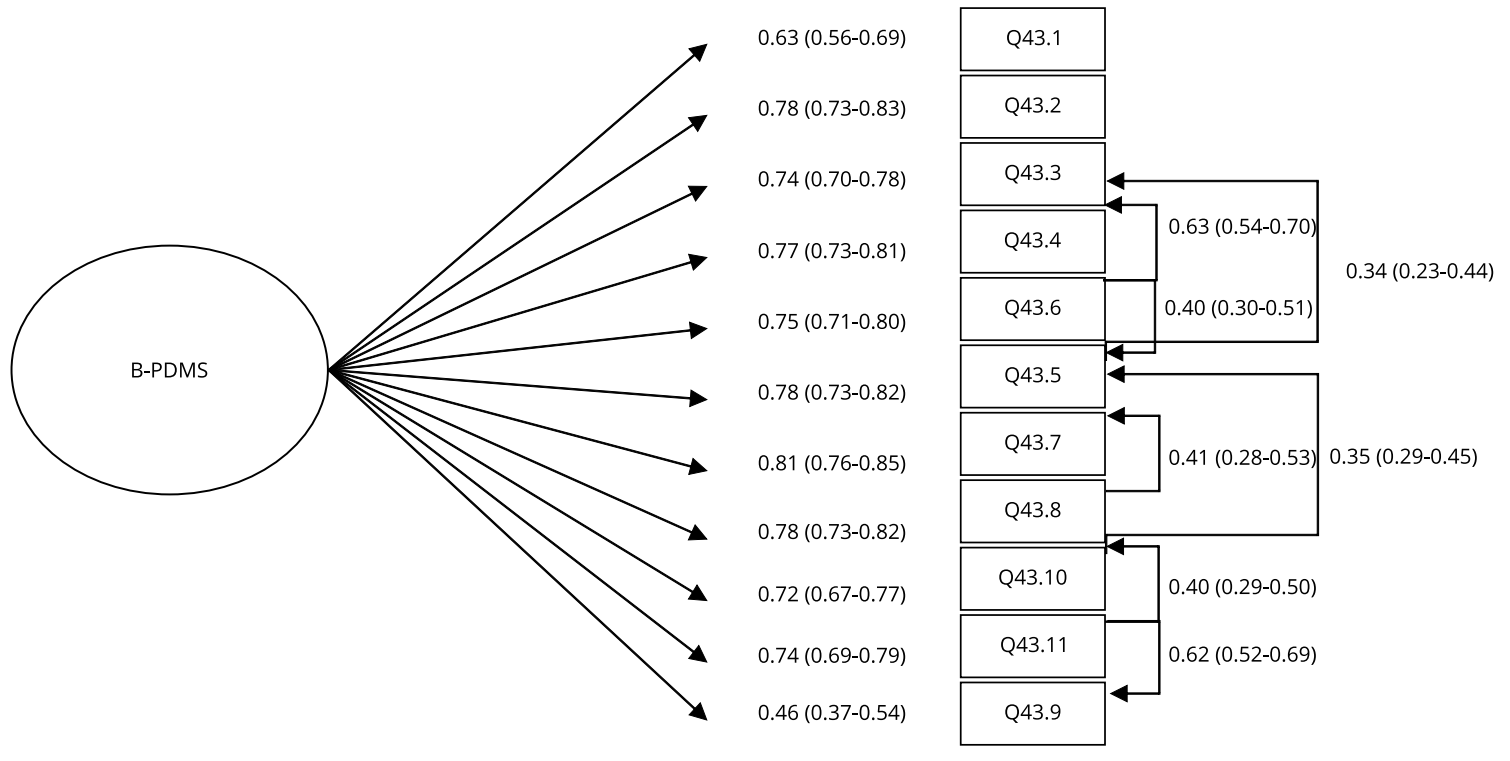

exerts an influence on pregnant women regarding health-related decision-making and communication with healthcare providers during prenatal appointments $1,4,5,6,11,12,13,14$.

The sample size was adequate for the evaluation of the psychometric properties of the B-PDMS $21,28,37$. For the confirmatory factor analysis, the ratio of 60 observations per item surpasses the methodological recommendation of 10 per variable 37 . The administration of the scale to the target population in virtual Facebook groups was more viable, considering many active groups of mothers and pregnant women in the social network and the ease of mobilizing participants to adhere to the study.

The Internet influence in increasing decision autonomy and preparing pregnant women for better communication with health professionals has been previously discussed in the literature $1,4,5,6,11,12,13,14$. The cross-cultural adaptation of the WUIPQ to Brazilian Portuguese and the validation of the B-PDMS indicate the possibility of the online use of the questionnaire and its wide-scale applicability to Brazilian pregnant women and mothers. The use of the B-WUIPQ and B-PDMS in future studies could help understand the usefulness of the Internet among pregnant women in the search for health-related information. These instruments can also help identify the potential of the Internet for empowering Brazilian pregnant women and its influence on the healthcare providerpatient relationship during prenatal care. Our results can also contribute to planning strategies for the more qualified use of online information during pregnancy.

A limitation of this study was that operational equivalence was not assessed, since the B-PDMS was not made available on websites targeted at pregnant women, as was the case with the original instrument. A convenience sample was used in a single social network that may be in disuse, so it is not possible to draw representative conclusions for the population. Thus, it is suggested that further studies should be carried out to build a set of evidence on the use of B-WUIPQ and B-PDMS in different Brazilian contexts. 


\section{Conclusions}

This study provides evidence supporting the cross-cultural validity of a Brazilian Portuguese version of WUIPQ that may be recommended to evaluate the use of the Internet among Brazilian pregnant women via online administration. The B-WUIPQ proved valid and reliable for its use on Brazilian pregnant women. This study also presented a reliable, valid scale adapted to Brazilian culture. The B-PDMS can be used independently to evaluate the influence of information from the Internet on health-related decision-making and communication with healthcare providers during prenatal care.

\section{Contributors}

A. C. C. Borges, R. C. Ferreira, M. F. Perazzo, and M. I. B. Senna participated in the conception and design, acquisition, analysis and interpretation of data, draft and revision of the article and final approval of the version to be published. L. G. Rodrigues and S. M. Paiva contributed in the draft and revision of the article and final approval of the version to be published.

\section{Additional informations}

ORCID: Ana Carolina Cleto Borges (00000001-9525-7447); Raquel Conceição Ferreira (0000-0001-8897-9345); Lorrany Gabriela Rodrigues (0000-0002-9531-5392); Matheus de França Perazzo (0000-0003-1231-689X); Saul Martins de Paiva (0000-0002-3968-1638); Maria Inês Barreiros Senna (0000-0002-0578-8744).

\section{Acknowledgments}

To Brazilian National Research Council (CNPq) and Brazilian Graduate Studies Coordinating Board (CAPES) for the scholarships of the authors L. G. Rodrigues and M. F. Perazzo.

\section{References}

1. Lagan BM, Sinclair M, Kernohan WG. internet use in pregnancy informs women's decision making: a web-based survey. Birth 2010; 37:106-15.

2. Hearn L, Miller M, Lester L. Reaching perinatal women online: The Health you, Healthy baby website and app. J Obes 2014; 2014:573928.

3. Jarlenski M, Tarr JA, Holland CL, Farrell D, Chang JC. Pregnant women's access to information about perinatal marijuana use: a qualitative study. Womens Health Issues 2016; 26:452-9.

4. Lagan BM, Sinclair M, Kernohan WG. What is the impact of the Internet on decision-making in pregnancy? A global study. Birth 2011; 38:336-45.

5. Bert F, Gualano MR, Brusaferro S, De Vito E, Waure C, La Torre G, et al. Pregnancy e-health: a multicenter Italian cross-sectional study on Internet use and decision-making among pregnant women. J Epidemiol Community Health 2013; 67:1013-8.

6. Scaioli G, Bert F, Galis V, Brusaferro S, De Vito E, La Torre G, et al. Pregnancy and Internet: socio-demographic and geographic differences in ehealth practice: results from an Italian multicenter study. Public Health 2015; 129:1258-66.

7. Prescott J, Mackie L. You sort of go down a rabbit hole... you're just going to keep on searching online for pregnancy-related information during pregnancy. J Med Internet Res 2017; 19:e194. 
8. Lima-Pereira P, Bermúdez-Tamayo C, Jasienska G. Use of the Internet as a source of health information amongst participants of antenatal classes. J Clin Nurs 2011; 21:322-30.

9. Criss S, Baidal JAW, Roberta E, Goldman RE, Perkins M, Cunnungham $\mathrm{C}$, et al. The role of health information sources in decisionmaking among Hispanic mothers during their children's first 1000 days of life. Matern Child Health J 2015; 19:2536-43.

10. Kavlak O, Atan SU, Güleç D, Oztürk R, Oztürk R, Atay N. Pregnant women's use of the Internet in relation to their pregnancy in Izmir, Turkey. Inform Health Soc Care 2012; 37:25363.

11. Huberty J, Dinkel D, Beets MW, Coleman J. Describing the use of the Internet for health, physical activity, and nutrition information in pregnant women. Matern Child Health J 2013; 17:1363-72.

12. Holtz B, Smock A, Reyes-Gastelum D. Connected motherhood: social support for moms and moms-to-be on Facebook. Telemed J E Health 2015; 21:415-21.

13. Bjelke M, Martinsson AK, Lendahls L, Oscarsson M. Using the Internet as a source of information during pregnancy: a descriptive crosssectional study in Sweden. Midwifery 2016; 40:187-91.

14. Fredriksen EH, Harris J, Moland KM. Webbased discussion forums on pregnancy complaints and maternal health literacy in Norway: a qualitative study. J Med Internet Res 2016; 18:e113.

15. Souza VB, Roecker S, Marcon SS. Ações educativas durante a assistência pré-natal: percepção de gestantes atendidas na rede básica de Maringá-PR. Rev Eletrônica Enf 2011; 13:199210.

16. Larsson MA. Descriptive study of the use of the Internet by women seeking pregnancy-related information. Midwifery 2009; 25:14-20.

17. Gao LL, Larsson M, Luo SY. Internet use by chineses women seeking pregnancy-related information. Midwifery 2013; 29:730-5.

18. Kohnheim-Kalkstein YL, Whyte R, MironShatz T, Stellmack MA. What are VBAC women seeking and sharing? A content analysis of online discussion boards. Birth 2015; 42:27782.

19. Sinclair M, Lagan BM, Dolk H, McCullough JEM. An assessment of pregnant women's knowledge and use of the Internet for medication safety information and purchase. J Adv Nurse 2018; 74:137-47.

20. Maher CG, Latimer J, Costa LOP. The relevance of crosscultural adaptation and clinimetrics for physical therapy instruments. Rev Bras Fisioter 2007; 11:245-52.

21. Terwee CB, Mokkink LB, Knol DL, Ostelo RW, Bouter LM, de Vet HC. Rating the methodological quality in systematic reviews of studies on measurement properties: a scoring system for the COSMIN checklist. Qual Life Res 2012; 21:651-7.
22. Kuhlthau CC. Inside the search process: information seeking from the users perspective. J Assoc Inf Sci Technol 1991; 42:361-71.

23. Kalbach J. Feeling lucky? Emotions and information seeking. Interactions 2004; 11:66-7.

24. Lagan BM. Womens' decision making in pregnancy: the role of the Internet [Doctoral Dissertation]. Belfast: University of Ulster; 2007.

25. Sayakhot P, Carolan-Olah M. Internet use by pregnant women seeking pregnancy-related information: a systematic review. BMC Pregnancy Childbirth 2016; 16:65.

26. Graham ID, O'Connor AM. User manual: preparation for decision making. https://deci sionaid.ohri.ca/docs/develop/User_Manuals/ UM_PrepDM.pdf (accessed on 20/Apr/2018).

27. Herdman M, Fox-Rushby J, Badia X. A model of equivalence in the cultural adaptation of HRQoL instruments: the universalist approach. Qual Life Res 1998; 7:323-35.

28. Beaton DE, Bombardier C, Guillemin F, Ferraz MB. Guidelines for the process of cross-cultural adaptation of self-report measures. Spine 2000; 25:3186-91.

29. Gjersing L, Caplehorn JR, Clausen T. Crosscultural adaptation of research instruments: language, setting, time and statistical considerations. BMC Med Res Methodol 2010; 10:13.

30. Borsa JC, Damásio BF, Bandeira DR. Adaptação e validação de instrumentos psicológicos entre culturas: algumas considerações. Paidéia 2012; 22:423-32.

31. Landis JR, Koch GG. The measurement of observer agreement for categorical data. Biometrics 1977 ; 33:159-74.

32. Hu L, Bentler PM. Fit indices in covariance structure modeling: sensitivity to under parameterized model misspecification. Psychol Methods 1998; 3:424-53.

33. Hu L, Bentler PM. Cutoff criteria for fit indexes in covariance structure analysis: conventional criteria versus new alternatives. Struct Equ Modeling 1999; 6:1-55.

34. Figueiredo-Filho DB, Silva-Junior JA. Visão além do alcance: uma introdução à análise fatorial. Opin Pública 2010; 16:160-85.

35. Lefèvre F, Lefèvre AMC, Madeira W. Hypertrofy of mediations, Internet and empowerment in the health-disease. Saúde Soc 2007; 16:149-57.

36. Schmidt E, Viana SMSA, Andrade EBM, Fernandes MD, Rezende SPI, Reis PVS, et al. The inclusion of Internet in patient-physician relationship. Rev Assoc Med Bras (1992) 2018; 64:297-8.

37. Streiner DL, Norman GR. Health measurement scales: a practical guide to their development and use. Oxford: Oxford University Press; 2008. 


\section{Resumo}

O estudo teve como objetivos, traduzir e realizar a adaptação transcultural do Women's Use of the Internet in Pregnancy Questionnaire (WUIPQ) para português do Brasil e analisar as propriedades psicométricas da Preparation for Decision Making Scale (PDMS). O estudo consistiu nas seguintes etapas: tradução, sintese, retrotradução, avaliação pelo autor do questionário original, revisão pelo painel de especialistas e pré-teste do WUIPQ. Gestantes e mães brasileiras que pertenciam a grupos de Facebook participaram no estudo. Medimos a confiabilidade teste-reteste e a consistência interna e realizamos análise fatorial confirmatória (AFC) do B-PDMS. No pré-teste, $88,14 \%$ das participantes consideraram os itens do B-WUIPQ claros e pertinentes, e 84,09\% avaliaram a sequência e organização do questionário como excelentes ou boas. Os coeficientes de correlação intraclasse e alfa de Cronbach para o B-PDMS foram 0, 850 (IC95\%: 0,791-0,899) $e$ 0,91 , respectivamente. A AFC revelou cargas fatoriais acima de 0,70 para a maioria dos itens, com um indice de ajuste comparativo de 0,989, indice de Tucker-Lewis de 0,984 e raiz da média dos quadrados dos erros de aproximação de 0,08 (IC95\%: 0,06-0,09). O B-WUIPQ apresentou boa adaptação transcultural, e o B-PDMS demonstrou propriedades satisfatórias para gestantes brasileiras.

Gestantes; Internet; Acesso à Informação; Comparação Transcultural; Inquéritos e Questionários

\section{Resumen}

El objetivo de este estudio fue traducir y adaptar transculturalmente el Women's Use of the Internet in Pregnancy Questionnaire (WUIPQ) al portugués de Brasil y analizar las propiedades psicométricas de la Preparation for Decision Making Scale (PDMS). Este estudio consistió en los siguientes pasos: traducción, sintesis, traducción inversa, evaluación por parte del autor del cuestionario original, revisión de un panel de expertos, y pretest del WUIPQ. Para ello, mujeres embarazadas brasileñas, y madres que eran miembros de grupos de Facebook, participaron en el estudio. Se midió la fiabilidad del test-retest y la consistencia interna, y se realizó un análisis factorial confirmatorio (AFC) de la B-PDMS. En los pretest, $88,14 \%$ de las participantes consideraron los items del B-WUIPQ claros y pertinentes, y un $84,09 \%$ calificaron la secuencia y organización del cuestionario como excelente/buena. El coeficiente de correlación intraclase y el coeficiente alfa de Cronbach para la B-PDMS fueron 0,850 (IC95\%: 0,791-0,899) y 0,91, respectivamente. El AFC reveló cargas factoriales superiores a 0,70 para la mayoría de los items, con un indice de ajuste comparativo de 0,989, índice de Tucker-Lewis de 0,984 y raíz de la media de los cuadrados de los errores de aproximación de 0,08 (IC95\%: 0,06-0,09). El B-WUIPQ demostró estar transculturalmente adaptado, y la B-PDMS mostró propiedades psicométricas satisfactorias para las mujeres brasileñas embarazadas.

Mujeres Embarazadas; Internet; Acceso a la Información; Comparación Transcultural; Encuestas y Cuestionarios
Submitted on 23/Dec/2019

Final version resubmitted on 29/Oct/2020

Approved on 23/Nov/2020 